\title{
Erratum to: Proceedings of the International Conference on Information Technology \& Systems (ICITS 2018)
}

\author{
Álvaro Rocha and Teresa Guarda
}

\section{Erratum to:}

\author{
Á. Rocha and T. Guarda (eds.), \\ Proceedings of the International Conference on Information \\ Technology \& Systems (ICITS 2018), \\ Advances in Intelligent Systems and Computing 721, \\ https://doi.org/10.1007/978-3-319-73450-7
}

\begin{abstract}
The original version of the book was inadvertently published with incorrect third author name as "Pablo Torres Carrión", which has been corrected as "Pablo Torres-Carrión" in Chapter 15, Frontmatter and Backmatter, and the affiliation of first and second authors "Faculty of Engineering Sciences, Universidad Tecnolgica Equinoccial, Quito, Ecuador" has been updated as "Faculty of Engineering Sciences, Universidad Tecnológica Equinoccial, Quito, Ecuador" in Chapter 49. The erratum book has been updated with the changes.
\end{abstract}

The updated online version of these chapters can be found at https://doi.org/10.1007/978-3-319-73450-7_15

https://doi.org/10.1007/978-3-319-73450-7_49 